\title{
Energy Consumption Regimes in the Arctic and Siberia: the Use of Resources by Indigenous People in the Context of Socio-Economic Change
}

\author{
Vladimir N. Davydov* \\ Peter the Great Museum of Anthropology and Ethnography \\ (Kunstkamera) RAS \\ 3 University emb., St. Petersburg, 199034, Russia \\ Chukotka branch of North-Eastern Federal University \\ 3 Studencheskaia Str., Anadyr, 689000, Russia
}

Received 02.03.2019, received in revised form 30.07.2019, accepted 06.08.2019

This article aims to stress poignant energy problems that have arisen among indigenous population in the Arctic and Siberia in the early $21^{s t}$ century and acquired a systemic character within the process of globalization. Until now, the study of energy processes and the analysis of the use of natural resources by indigenous peoples were considered as two distinct areas of research, barely intersecting each other. This paper aims to deconstruct the border between them and to discuss the exploitation of resources by local population of the Arctic and Eastern Siberia in the context of contemporary industrial development projects, rationalization of local economic activities and introduction of new infrastructure, technologies and equipment.

Keywords: energy regimes, renewable resources, appropriation of the landscape, socioeconomic change, indigenous people, Arctic, Eastern Siberia, infrastructure, adaptation strategies.

The present research has been supported by the grant of the RSF project "Energy of the Arctic and Siberia: The Use of Resources in the Context of Socio-Economic and Environmental Changes" (No. 18-18-00309).

Research area: ethnography, ethnology and anthropology.

Citation: Davydov, V.N. (2019). Energy consumption regimes in the Arctic and Siberia: the use of resources by indigenous people in the context of socio-economic change. J. Sib. Fed. Univ. Humanit. soc. sci., 12(8), 1391-1407. DOI: 10.17516/1997-1370-0456.

(C) Siberian Federal University. All rights reserved

* Corresponding author E-mail address: davydov.kunstkamera@gmail.com ORCID: 0000-0003-2738-4609

This work is licensed under a Creative Commons Attribution-NonCommercial 4.0 International License (CC BY-NC 4.0). 


\section{Introduction}

The problem of choosing a direction of modernization and finding new sources of energy in the Arctic - the question that remains unresolved. This makes the study of sources of energy and their utilization and conservation by the northern communities, as well as the adaptation of the inhabitants of the North and Siberia to the socioeconomic and environmental changes especially important.

The article will discuss the use of resources by indigenous population of the Russian Arctic and Eastern Siberia in the context of the functioning of the contemporary industrial development projects, rationalization of local economic activities and introduction of new infrastructure, technologies and equipment. It will include the examples of the fieldwork of the author among Evenki, Dolgan and Chukchi indigenous communities in Taimyr, Chukotka, northern Buryatia, Zabaikal'skii krai, Olekminskii district of the Sakha (Yakutia) Republic and in the Amurskaia oblast' where the author totally conducted about 32 months of fieldwork during last 12 years. The current research is a part of the project supported by the Russian Scientific Foundation (grant No. 18-1800309). The project is focused on everyday use of energy resources by the indigenous people, production, utilization and accumulation of energy and the social dimension of these processes in Siberia and the Arctic. It also investigates the role of exchange and the adaptation of multiple sources. It is also deigned to analyze the experience of the use of alternative energy sources, new vehicles and their impact on the existing model of utilization of natural resources.

Until now, the study of energy processes and the analysis of traditional use of natural resources in the Arctic and Siberia were considered as two distinct areas of research, barely intersecting each other. Therefore, the distance between these two areas should be reduced to elaborate a new way of interpreting the local ways of interacting with the environment in the context of the use of local energy resources.

\section{Energy consumption regimes and use of space}

Historically, in the conditions of the Russian Arctic and Siberia, certain energy regimes (modes of energy consumption), which implied particular methods of use of environment based on the combination of multiple sources of energy obtained through various activities including exchange, have been developed. Relying on certain technologies of energy accumulation and through the use of combination of energy sources, local people of the Arctic and Siberia managed to appropriate large territories. However, during the introduction of various innovations in the $20^{\text {th }}$ - early 
$21^{\text {st }}$ centuries, sustainable methods of interaction between the local population and the environment, allowing organizing the optimal use of resources while maintaining the subsistence system, became destroyed.

Contemporary economic practices have a strong impact on the existing energy consumption regimes, as well as considerably transform social institutions. The changes in these regimes were supplemented by the formation of certain communities and practices. Indigenous people are often treated in Anthropology as victims of energy regimes imposed by the government and extractive industry, but this view creates a somewhat simplified picture of energy processes. In many places people actively used the infrastructure and equipment introduced during the process of industrial development.

Significant changes occurred in the ways of how people used space. For instance, starting from the 1970s, reindeer herders of Chukotka started to employ heavy equipment such as ATVs, tractors and snowmobiles. There are local particularities of how people use them. In Taimyr, people travel on snowmobiles not only in winter, but also during summer. A few years ago, reindeer herders in Taimyr started using quad bikes. At the same time, they continue using sledges. Yet, local people had to modify them - they started using new materials and technologies to construct sledges. They were adapted to the transportation of people and cargoes by means of snowmobiles. To increase the carrying capacity of sledges used with snowmobiles, they started to make them wider than ordinary reindeer sledges. As a matter of fact, their construction in many regions changed due to introduction of snowmobiles. Local people were very creative in adapting sledges to new conditions. They need larger sledges to be able to move larger amount of cargo and number of people by the use of one particular vehicle.

The emergence of new technical equipment and fuel in hunters' and reindeer herders' communities in the Arctic and Siberia is largely the result of the exchange with neighbors and extracting companies. Delivery of new equipment and vehicles requires significant economic costs. In Taimyr, for some local residents, the opportunity to purchase modern vehicles became possible due to a high value of mammoth tusks they can find in the tundra as well as by selling meat and fish. When people sell these products to entrepreneurs, they purchase vehicles, first of all snowmobiles, quadricycles, ATVs and boat motors. These vehicles, in turn, allow them to get and export products of hunting and fishing to local centers. Fish, meat, antlers, horns - all this basically goes in exchange for fuel and vehicles. Dolgans in Taimyr sometimes directly exchange meat and fish to barrels with fuel, which they need for movements. In this sense, the 
equipment allows local people searching resources, which they exchange for fuel and this helps them to facilitate mobility.

The transition to market economy had a strong impact on daily practices of the local population in the Arctic and Siberia and significantly changed the ways in which resources were obtained and used. The political changes associated with the transition to market economy had a strong impact on the everyday practices of indigenous people of the North, and significantly changed the technologies of production and utilization of energy resources.

In many northern regions people began to use the local natural resources more intensively, primarily due to growing unemployment. This, in turn, affected the ecosystem. For instance, both the intensive fishery and ecological changes led to decrease of the population of Arctic Cisco in Lake Baikal region. This tendency led to the prohibition of the all methods of fishery in 2017 and indigenous quotas which were available for northern Baikal Evenkis were cancelled. However, it resulted with a noncomplaint behavior of local fishermen.

\section{Relative autonomy and resource shortage}

The use of energy sources in the Arctic and Siberia always took place within the framework of socio-economic transformation in the context of relative autonomy of local population. The practice of autonomous existence for certain periods of time characterize hunters' and reindeer herders' in the northern communities. Residents of the North and remote Siberian territories, living and working in a situation of remoteness from the places of resources distribution, developed the skills of autonomous existence in the tundra and taiga. These skills included the existence of certain periods of time without additional supply of food, tools, clothing and fuel. The joint movements of people and domestic animals (reindeer, dogs) made it possible to maintain a high degree of autonomy in the economy, movement and communication (Golovnev, 2015: 9).

The ways of how the inhabitants of the North use space should be analyzed from the point of view of the strategy of energy conservation, minimization of its consumption in the conditions of long-term autonomy, which led them to development of certain nomadic technologies (Golovnev, 2016), allowing them to change their location in space rather fast, moving together with animals and things relatively long distances.

Local indigenous population developed skills of producing tools, clothing and vehicles, as well as repairing them. They have mastered the ways of economical use 
of resources. At the same time, they learned how to combine various energy sources, which included not only natural objects and phenomena, but also the infrastructure created by the state and extractive companies, which helped people to overcome the risks of their shortage.

Thus, local population learned how to combine different sources of energy, which included infrastructure created by the state and mining companies, as well as natural objects and processes, struggling with the risk of energy shortage. The use of vehicles and the use of infrastructure has become an integral part of the technologies of space appropriation by northern hunters and reindeer herders. Infrastructure had a significant impact on their mobility, providing new opportunities for movement, storage and exchange, intensifying movement in certain places and changing nomadic routes.

In the North, it is important not only to produce energy, but one needs also to preserve it. Skills played an important role in this process - people acquired an ability to use a variety of energy sources, and their combinations. Traditionally, the indigenous peoples of the North and Siberian Russians created a variety of equipment, clothes, instruments, tools, dwellings and vehicles which allow more efficient use of energy resources at the conditions of low temperatures and extreme remoteness from the distribution points of imported goods. An important role here is played by both economic and social practices - exchange, cooperation, mobility and intensive use of different types of landscapes.

Within the framework of the dominant scientific paradigm, energy was associated with industrial development, the extensive development of the territories, and the work of plants. At the same time, relatively small sources of energy which local people used in their daily tasks were underestimated. The opinion that the state had imposed energy regimes to local indigenous population can be found in the scientific literature rather often.

The focus of the analysis was centered on the conflict between indigenous population and migrants concerning the use of resources, when the representatives of indigenous people were considered primarily as victims of the practices of the dominant majority (Thuen, 2004). This paradigm was based on 'archaeological approach' to energy where researchers analyzed some facts and results and the events were reconstructed based on these results. Ethnographers often give detailed descriptions of different material objects and technologies as well as the economy of northern communities. Yet, in order to understand the changes, which occur in the northern communities, we have to see a consumption of energy sources as a united system where one element is connected 
with others. In case the balance between elements changes, it simultaneously has an impact on the whole system.

The objects people use in everyday life can be seen as a united complex, which forms a particular energy consumption regime. S. M. Shirokogoroff (1929) in his famous work "Social organization of the northern Tungus" suggested the concept of ethnographic complex (Shirokogoroff, 1929) in order to interpret the things, which different Tungus groups use, as well as their actions as a united system. The concept of a "system of things" was expressed by a French sociologist and postmodern philosopher J. Baudrillard (1996). The idea of a complex of equipment was developed in soviet ethnography in the well-known "Historical-Ethnographical Atlas of Siberia" (Levin and Potapov, 1961). Different types of connections between different material things and actions was suggested in works of Tim Ingold through the introduction of the concept of meshwork (Ingold, 2007: 80, 2011: 67-94), borrowed from philosopher Henri Lefebvre (Lefebvre, 1991: 117-119). These ideas can help a researcher to see a complex of relations between different phenomena and can be applied to the research everyday use of resources by local people. People from the northern regions consume energy extracted from various sources where one is connected with others as a kind of meshwork.

Thus, a methodologically important aspect of the study of energetic processes is a shift from the analysis of individual operations, where energy is used, to research of the relationships between these operations and approaching these relations as networks which form a particular energy consumption regime. This allows to see energy sources as a system composed from certain elements which can be combined, replaced by the harsh environmental conditions in the process of appropriation of different landscapes.

Even though local people extract and consume energy received from a set of multiple sources, ethnographic texts often represent various activities as separated and independent from each other. The set of these practices constitute a particular energy regime that should be approached as a complex combination of different activities. Therefore, the focus of the analysis should be shifted to a comprehensive and integrated combination - a sort of a network of various activities; this is what allows the inhabitants of the northern regions to provide themselves with energy resources in a condition of extreme remoteness from the centers and from neighboring settlements.

Both economic and social practices play an important role here. These are sharing of resources, cooperation, mobility and intensive use of various types of landscapes. Energy resources can act as exchange equivalents in relations between different social 
agents. Through involvement in social relations at both local and global levels, the residents of the Arctic and Siberia are able to receive both traditional and recently introduced energy sources. A production of energy is a result of social interaction and exchange with other people and with the environment, including various ceremonial actions.

The search for different kind of resources includes the informal economy and exchange practices. Local people of the Arctic and Siberia are familiar with a shortage of resources, which are often acquired by violations of the law (the excess of hunters and fishermen quotas for the purpose of food production, logging, etc.). The noncompliance with law in the use of local resources is largely stimulated by the demand for products of hunting and fishing on the black market as well as by a high level of hidden unemployment. Access to resources of the various categories of population is limited by the current legislation, determining the order of their use by establishing quotas, seasonal and technological limitations. However, in practice, especially in a highly competitive environment, these quotas do not work.

The use of a set of tools, instruments, vehicles, equipment, clothing and technologies creates a certain synergetic effect which helps local people to increase the potential energy. The energy can also be increased by the strategies of re-use of resources. Taiga provides people by wood - a source of building materials and allows people to organize bases. Evenkis use numerous places where they keep things in the taiga. Situation in the tundra the is somewhat different. People often need to move property and building materials with them. They have to do this in advance by planning a route and making supplies of fuel and food. Nature seemed to have taken care of the inhabitants of the Arctic by providing the resources necessary for the survival of humans and the animals which move with them. At the same time, people have learned to combine these sources, solving the problems of their transportation and storage.

The village of Syndassko in Taimyr, for example, often lacked of imported coal. Therefore, local people have to extract coal themselves on the shores of the Khatanga Bay. In summer they gather wood brought by water (plavnik). It serves as an important building material and a source of heating. However, climate and weather change can affect the quality and quantity of wood. It is very important to choose the time to collect it correctly and to deliver it to the set of places where people will need firewood during their movements. In this context, hunters and reindeer herders employ equipment and infrastructure brought and built within development projects. 
Within the soviet ideology the infrastructure and equipment were represented as a kind of "gift" which was seen as an achievement of the political regime, which made the life of indigenous people more modernized, comfortable and mobile (Ssorin-Chaikov, 2003). Trying to advocate the idea of the need to change out-of-date infrastructure and equipment, the administrative discourse tried to put them into the context of a particular temporal regime, representing it as more modern in relation to traditional technologies of movement, that created the image of the ethnographic reality, as if it was based on two different temporalities (Ssorin-Chaikov 2017), and separated the infrastructure and surrounding landscape. This kind of division led to dichotomies between anthropogenic and natural landscape, settlements and surrounding places in the tundra and taiga, traditions and innovations.

\section{The use of innovations and old technologies}

Many social scientists concentrated on the investigation of mobility and new mobile technologies. Anthropological works paid a lot of attention to the description of the practices of use of natural landscape via traditional technologies as contrasted with innovations, which made "revolutions" and radically changed the ways of how local people used space and transformed social relations (Pelto, 1973). Starting from the 1970s anthropologists started to discuss either different sorts of revolutions or provide critical incites by providing local examples how the concept of revolution does not work. The research at Yamal, which was recently conducted made by Alexandra N. Terekhina and Alexander I. Volkovitskii and presented at the "Polar readings" conference in 2018, demonstrate that reindeer herders adapt innovations, but at the same time continue to use old patterns of mobility where they employ reindeer.

As a matter of fact, this observation can be supported by many ethnographic examples in other northern regions. In many cases people combine the use of various options in order to secure and rationalize their activities. For instance, in the northern Baikal the soviet authorities proposed a project of Evenki sedentarization. Many authors of the 1920s wrote that nomadism is something backward and should be replaced by a more sedentary type of reindeer herding, e. g. log house (izbennoe) reindeer herding. Thus, the village of Kholodnaia in the Northern Baikal region was built as a part of this project. The administrators organized the construction of log houses in the newly created village. They expected that people would permanently live at these houses. However, the visiting specialists from Verkhneudinsk (UlanUde) were surprised that local hunters and reindeer herders simultaneously used two 
villages - new 'tungus settlement' and the village of Dushkachan - the former center of the Kindigir indigenous administration (rodovoe upravlenie), where some of them had possessed houses before (Zabelin, 1930: 55). It means people extended their possibilities for exchange, keeping property and rationalized movements by the appropriation of the new infrastructure in the village. They used the houses for keeping things and temporary stay, and both villages served as points of their periodic returns.

Thus, an old form does not necessarily disappear, but can act parallel to a new one. This, however, does not mean that two ethnographic realities consisting from the followers of traditions and proponents of innovations exist parallel to each other. Even though the innovation increases the spectrum of opportunities, local people start to use them and can continue employing well known to them technologies. For instance, Dolgan reindeer herders use both new vehicles and reindeer transport. This helps people to minimize the costs of fuel and its transportation.

Even though reindeer herders and hunters use many innovations, they continue using self-made tools and old technologies of their production (Brandišauskas, 2017), with the use of new materials. Nomadic groups of the Arctic use a strategy of minimalism in property and consumption of resources (Golovnev et al., 2016). This is a way of space appropriation with the minimum consumption of energy and includes technological minimalism. The use of infrastructure is connected with this strategy because it can decrease consumption of people's energy in building and mobility. It became possible due to the development of the creation of storages for keeping things. Earlier reindeer herders transported more things than they do nowadays.

Successful inventions as well as the technologies of materials' replacement are spreading very fast. At the same time many objects have their authors. People may use those things not being aware of people, which had actually created them. The inventions were connected with particular people and widely spread after people had seen that they worked effectively. For instance, Grigorii Mikhailovich Rakylym from Amguema in Chukotka invented specific connections between various parts of a sledge with the use of holes and ropes and developed the ergonomics of a sledge used with a snowmobile. He also adapted to cover skids of sledges by a plastic cut from black tubes - the remains of Iul'tin's infrastructure, that provides much better glide on the snow. According to him, this was a result of numerous tests. As soon as he received the necessary result, the invention spread very fast and people rapidly employed it in neighboring villages. The production of sledges, according to him is a kind of science. It is very important to provide the minimal resistance of air and 
surface within movement. Grigorii Mikhailovich also invented a sledge for children and it spread in the region with some modifications. Every craftsman usually adds something from him, yet the form and proportions can be preserved.

Similarly, Dolgans in Taimyr cover skids of sledges by plastic taken from similar polyethylene plastic tubes, which became a universal material in the Arctic. In Chukotka people produce a number of useful things from them. Reindeer herders carve a stick for cleaning snow which was traditionally made from reindeer horns. They also make plastic details for lassoes.

\section{Appropriation of the landscape: the use of infrastructure}

The logic of how indigenous people use anthropogenic landscape has many similarities with the ways they appropriate natural landscape. In this sense, the border between them is not so strict. In the post-Soviet period the problem of deficit of building materials, tools and spare parts for equipment became very poignant for northern and Siberian settlements. The elements of abandoned anthropogenic landscape became a sources and storages of building materials and fuel and became actively used by local people. They often created constructions, tools and vehicles by the use of means and materials they had at hands and which they escalated at the abandoned objects.

Scientific approach saw anthropogenic landscape as contrasted with natural landscape. It was often based on a narrow definition of anthropogenic landscape where scientists interpreted it as a landscape produced for particular purposes, strongly changed by humans and which included cities and factories (Reimers and Iablokov, 1982: 68). Nevertheless, most landscapes contain the signs of a direct and indirect anthropogenic impact. In this context, it is difficult to draw a strict border between anthropogenic and natural landscape. Both natural phenomena and human actions affect the objects which were created by people. Technical innovations, new vehicles and extraction of natural resources has a serious impact on environment. The changes can be initiated by almost any practical activities. Particular changes can be traced in case of reindeer herding. For instance, in Taimyr where people conduct work with the herd in the end of summer in a corral to divide a herd and to vaccinate animals, the vegetation rehabilitates itself for many years (Davydov, 2018).

Local people in the Arctic and Siberia adapt and transform things that they can get at the moment, constructing new buildings and producing things from improvised 
means. As a result, the initial functions of them can be changed and things can acquire new forms. In case of the use of abandoned infrastructure and equipment people gradually utilize them, using their parts as building materials and fuel. This practice implies a re-use, repair, reshaping and creative modification of old things and their parts. In this sense, "abandoned" by the state and industrial enterprises infrastructure is not left by people. For instance, people use old abandoned ship instead of a berth near Syndassko in Taimyr. In a similar manner a ship on the shore of the river in Khatanga serves instead an office to sale tickets.

General thing we can observe among indigenous people in the Arctic and Siberia is the process of substitution of objects, their parts and materials. The lack of particular things and materials is usually compensated by the adaptation of the new sources. In many cases people keep the form but employ something new. They often take into consideration the new qualities of the materials. For instance, Evenkis may use plastic instead skins and birchbark for covering tents. In this context, energy sources can be seen as a system which consists of elements, which can be combined and replaced. For instance, wooden parts of old constructions and planks from wooden boxes can be used instead of firewood. People are very creative in their excavation of materials from old things and structures. They employ wooden planks, sheets of metal, old nails, wheels from perambulators and trolleys, metal pipes and etc.

Transport infrastructure is very important for indigenous people - they use roads, bridges, embankments, even though they are very limited in some regions. Reindeer herders in many places employ the existing roads and paths to get to camps. Roads and new vehicles intensify pendulum movements between settlements and bases. These processes had a significant influence for the change of mobility patterns. For instance, the opportunity to keep things and food in settlements and bases as well as new vehicles lets reindeer herders to nomadize with smaller number of things and leads to decrease of the number of sledges used for transportation. Nowadays in most reindeer herders' brigades in Chukotka people change the location of their camps only by the use of equipment.

In recent years reindeer herders' mobility patterns significantly changed. For instance, Evenkis of the northern Baikal do not use sledges anymore. They employ heavy trucks and snowmobiles instead of reindeer transport. However, the appropriation of new things and vehicles is not a unique feature of contemporary life. In $19^{\text {th }}$ century in this region a sledge itself was an innovation and was adapted from the neighboring groups. In Taimyr the number of reindeer herders' moves within summer gradually 
decreases. This can be tracked in their diaries where people write down the places of their temporary camps. For instance, a reindeer herders' brigade (brigada) from the village of Popigai in summer of 2013 made more than 20 moves and just 13 moves in 2016. In many brigades both in Taimyr and Chukotka people use snowmobiles and quadricycles. Nevertheless, high costs of fuels stimulate reindeer herders to continue using reindeer transport in some places.

The use of equipment led reindeer herders to decrease the number of brigades, changing constant stay with herds to a kind of shift work (Golovnev et al., 2015: 57). This type of employment is based on the pendular movements to the place of work and back. Reindeer herders' movements were facilitated by the use of snowmobiles and boat motors - this made the travel between settlements and camps much faster. Dolgans from north-eastern Taimyr use snowmobiles to travel rather long distances to the neighboring settlements in Sakha (Yakutia) Republic to purchase goods and to visit relatives and friends.

Mobility implies the appropriation of the intensively used places, which people employ as points of constant return. Nomadic landscape can be seen as consisting of spatial centers, every of each can serve as a reference point (Hastrup, 2009). These logistical hubs often appear in the places where the buildings and infrastructure had existed. The use of infrastructure helps to economize peoples' efforts within movements. There are many examples of the abandoned settlements in Siberia and in the Arctic (e. g. Kosistyi in Taimyr, Iul'tin in Chukotka). Many people dismantle old buildings to get firewood and building materials. For instance, in 2015 local people from the village of Novorybnoe completely took to pieces an abandoned building of an old store. In Popigai people often used for firewood wooden poles of a corral, which were left in the settlement by veterinarians. People used excavated wooden parts in the abandoned building of the old house of culture. Thus, old buildings and infrastructure are the alternative sources of materials. Compared with the taiga, it is rather difficult to find building materials in the tundra. Arctic hunters often create cabins from improvised and delivered from other places materials.

In Taimyr reindeer herders use tents and rectangular wooden frames covered by furs (balok). Chukchi reindeer herders construct both tents and traditional dwellings (iaranga). In recent times reindeer herders started using tents covered by tarpaulin and furs. They say that such dwellings are much warmer than iarangas. Moreover, a weight of dismantled tent is smaller and it can be build much faster. Tents, which are rather new type of dwelling in the Amguema tundra, differ from brigade to brigade. Some 
of them contain the division of space, which is similar to iaranga. They include the internal curtains ( $p o l o g$ ) made from fur. In Chukotka reindeer herders started heating tents with kerosene stoves.

In many respect, mobility can be facilitated by the use of infrastructural objects serving as points of constant return, which can both static and mobile. Many things which can be seen as a garbage are actually used by local people. For a more practical organization of mobility people need to leave equipment and part of things in storages. There are many similarities in different regions of the Arctic and Siberia. Sheds and barns are often built from any available materials. People use them in many ways and their inventions widely spread and became typical features of anthropogenic landscape in the Arctic and Siberia and make it look futuristic.

People use particular modules they use to appropriate space. One of those is an iron container - a widely spread element of the anthropogenic landscape, and can be seen almost everywhere, especially in the places supplied by water transport. We can see a large number of different sorts of self-made sheds and industrially built containers. In Chukotka and Taimyr, they can be found in any settlement.

Local people frequently keep containers and sheds in neighboring settlements. For instance, in Chukotka inhabitants of Vankarem and Nutepel'men often keep tools and vehicles in Amguema. They visit this settlement on the way to regional center Egvekinot. In similar manner dwellers of Taimyr villages may store their property in Khatanga.

In the northern regions an iron container is a very practical place for keeping things. People use it for keeping tools, products, motors and vehicles. People employ any containers which can be closed. It can be a barrel, a metal tank, a trailer, a cabin from a ship, a big metal box. One person usually uses several containers which are not necessarily located in one place and sorting things between them, e. g. keeping clothes in one of them, tools and vehicles - in another. In Khatanga almost any fisherman uses a special shed or container.

In Amguema a construction of special blocks of containers was initiated by the local administration. The creation of these storages was a part of a settlement territory improvement project. They were built rather far from the houses where people lived. Therefore, local dwellers themselves put own containers, sheds, garages and greenhouses nearby the houses, even though it was officially prohibited by the administration. People in Amguema are very inventive in organization of storages for food and equipment. In many houses they use several refrigerators and deep-freezers. 
Altogether this equipment consumes a lot of energy. Therefore, in winter people try to keep products in containers, sheds and also produce self-made "Chukchi fridges" by hanging bags and boxes outside the window.

There are a plenty of ways how local inhabitants use iron fuel barrels in the Arctic and Siberia. In Taimyr they use metal parts of the barrels as a universal building material. Huge dumps containing old barrels are often accompany northern villages and shift-workers' settlements. Barrels can be transformed to stoves and employed for heating and cooking food, they can be adapted as parts of self-made vehicles and trolleys. Barrels can be used completely or by parts. People use them for keeping and transporting water. Finally, they extract iron and use it to cover walls and roods of different sorts of buildings and fences instead of siding to make them more wearproof. Empty barrels can be used as landmarks in tundra, since they are visible in winter time.

Within the state programs the representatives of northern indigenous peoples in Chukotka and Taimyr received subsidies for building houses in settlements. As a result, one can see in the northern settlements several layers of building projects houses built by kolkhozes and sovkhozes as well as contemporary houses, covered by siding and built on piles foundation. In Chukotka in Amguema at the beginning of the 2000s almost all old houses were dismantled and new cottages were built. Depending on the square local people call newly built blocks of houses "Shankhai" (small houses) and "Rublevka" (spacious and comfortable houses with several rooms and large kitchens). This division can be met in many settlements in Eastern Siberia. In 2015-2016 people working in the tundra received dotation for building houses in the villages of Novorybnoe, Popigai and Syndassko in Taimyr. People often rebuilt these new houses. Almost all inhabitants of these new houses construct additional porches for better saving of warmth.

\section{Conclusion}

Through use of new houses, sheds, workshops and garages local people appropriate the places more effectively. Infrastructure which was created during industrial development projects became gradually incorporated into their way of life to help them perform daily tasks. This took place in the context of a creative process, which changed the functional meaning of abandoned infrastructure and equipment. In many cases people replaced old materials by new that help them to rationalize their everyday practices. 
The appropriation of infrastructure by northern peoples is the result of a reflexive process (Davydov, 2017), which does not make a clear boundary between the natural and anthropogenic landscape. Hunters and reindeer herders gradually utilize some of the abandoned materials and equipment, modifying and adapting them for their needs and for mobility. This allows them to accumulate and distribute the energy they need for mastering the space. At the same time, the introduction of new technical innovations is combined with the use of old technologies. Relying on the methods of accumulating energy developed in the framework of practical activity, as well as combining the use of various resources, the inhabitants of Siberia and the Arctic managed to appropriate huge territories. The energy, used by these people, can be seen as a result of an exchange, interactions and social relations, as well as a creative synthesis, involving the use of multiple energy sources within a particular spatial organization of material objects. Therefore, Arctic and Siberia should be seen not as a territory of experiments carried out just by the external forces, but as a space of creative synthesis and inventions made by local people, where they themselves maintain and gradually transform particular energy consumption regimes.

\section{References}

Baudrillard, J. (1996). The system of objects. London: Verso, 205 p.

Brandišauskas, D. (2017). Starye tekhnologii i sovremennoe izgotovlenie taezhnogo snariazheniia u evenkov Zabaikal'ia [Old technologies and contemporary production of taiga equipment among Zabaikal Evenkis]. In Izvestiia Laboratorii drevnikh technologii [Reports of the Laboratory of Ancient Technologies], 13 (3), 44-77.

Davydov, V.N. (2017). Temporality of Movements in the North. In Sibirica, 16 (3), 14-34.

Davydov, V.N. (2018). Emotsii v otnosheniiakh cheloveka, zhivotnogo i landshafta: issledovanie koral'nykh rabot na Taimyre [Emotions in human-animal-landscape relations: The research of corral works in Taimyr]. In Kunstkamera [Kunstkamera], 2, 81-87.

Golovnev, A.V. (2015). Arkticheskaia mobil'nost': technologii i strategii [Arctic mobility: technologies and strategies]. In Severo-vostochnyi gumanitarnyi vestnik [Northeast humanitarian journal], 13 (4), 7-11.

Golovnev, A.V. (2016). Kochevniki arktiki: strategii mobil'nosti [Arctic nomads: strategies of mobility]. In Arkheologiia, etnografiia $i$ antropologiia Evrazii [Archaeology, Ethnography and Anthropology of Eurasia], 44 (4), 131-140. 
Golovnev, A.V., Garin, N.P., Kukanov, D.A. (2016). Olenevody Iamala (materialy $k$ atlasy kochevykh tekhnologii) [Yamal reindeer herders (materials for the atlas of nomadic technologies)]. Yekaterinburg: UrO RAN, 152 p.

Golovnev, A.V., Perevalova, E.V., Abramov, I.V., Kukanov, D.A., Rogova, A.S. and Usenyuk, S.G. (2015). Kochevniki Arktiki: Tekstovo-vizual'nye miniatiury [Nomads of the Arctic: text-visual small essays]. Yekaterinburg: "Alfa print", 132 p.

Hastrup, K. (2009). “The Nomadic Landscape: People in a Changing Arctic Environment.” In Geografisk Tidsskrift — Danish Journal of Geography, 109 (2), 181189.

Ingold, T. (2007). Lines: A Brief History. London: Routledge, 186 p.

Ingold, T. (2011). Being Alive: Essays on Movement, Knowledge and Description. London: Routledge, 288 p.

Lefebvre, H. (1991). The Production of Space. Oxford: Blackwell, 454 p.

Levin, M.G. and Potapov, L.P. (Eds.) (1961). Istoriko-etnograficheskii atlas of Siberia [Historical and Ethnographic Atlas of Siberia]. Moscow: Izdatel'stvo Akademii Nauk SSSR, 498 p.

Pelto, P.J. (1973). The Snowmobile Revolution: Technology and Social Change in the Arctic. Menlo Park, CA: Cummings Publishing Company, 225 p.

Reimers, N.F. and Iablokov, A.V. (1982). Slovar' terminov i poniatii, sviazannykh s okhranoi zhivoi prirody [Dictionary of terms and concepts related to the protection of wildlife]. Moscow: Nauka, 143 p.

Shirokogoroff, S.M. (1929). Social Organization of the Northern Tungus. With Introductory Chapters Concerning Geographical Distribution and History of these Groups. Shanghai: The Commercial Press, Ltd, 427 p.

Ssorin-Chaikov, N.V. (2003). The Social Life of the State in Subarctic Siberia. Stanford, CA: Stanford University Press, $280 \mathrm{p}$.

Ssorin-Chaikov, N.V. (2017). Two Lenins: A Brief Anthropology of Time. Chicago: Hau Books, The University of Chicago Press, $150 \mathrm{p}$.

Thuen, T. (2004). Anthropological knowledge in the courtroom. Conflicting paradigms. In Social Anthropology, 12 (3), 265-287.

Zabelin, K.A. (1930). Ocherki po ekonomike Severo-Baikal'skogo raiona [Essays on the economy of the northern Baikal region]. In Zhizn' Buriatii [Life of Buryatia], $4,35-57$. 


\title{
Режимы потребления энергии в Арктике и Сибири: \\ использование ресурсов коренным населением \\ в контексте социально-экономических изменений
}

\author{
В.Н. Давыдов \\ Музей антропологии и этнографии \\ им. Петра Великого РАН (Кунсткамера) \\ Россия, 199034, Санкт-Петербург, \\ Университетская наб., 3 \\ Чукотский филиал федерального государственного \\ автономного учреждения высшего образования \\ «Северо-Восточный федеральный университет \\ имени М. К. Аммосова» \\ Россия, 689000, Анадырь, ул. Студенческая, 3
}

Цель данной статьи - рассмотреть острые энергетические проблемы, которые возникли у коренного населения в Арктике и Сибири в начале XXI века и приобрели системный характер в прочессе глобализаџии. До настоящего времени изучение энергетических прочессов и анализ использования природных ресурсов коренными народами рассматривались как две отдельные области исследований, слабо пересекающиеся друг с другом. В данной работе была предпринята попытка объединить эти две сфеpы, проанализировав стратегии использования ресурсов местным населением российской Арктики и Восточной Сибири в контексте современных проектов промышленного развития, раџионализации экономической деятельности, внедрения новой инфраструктуры, технологий и оборудования.

Ключевые слова: энергетические режимы, возобновляемые ресурсы, освоение ландиафта, экологические и сочиально-экономические изменения, коренные народы, Арктика, Восточная Сибирь, инфраструктура, адаптационные стратегии.

Работа выполнена за счет гранта Российского научного фонда (проект № 18-1800309), проект «Энергия Арктики и Сибири: использование ресурсов в контексте сочиально-экономических и экологических изменений».

Научная специальность: 07.00.07 - этнография, этнология и антропология. 